\title{
TERTIARY EDUCATION TRUST FUND (TETFUND) AND THE MANAGEMENT OF UNIVERSITY EDUCATION IN NIGERIA
}

\author{
VICTORIA C. ONYEIKE AND EMMANUEL O. ESEYIN
}

(Received 25, March 2014; Revision Accepted 8, May 2014)

\begin{abstract}
The paper examines the role of the Tertiary Education Trust Fund (TETFund) in the management of University education in Nigeria. A brief history of University education in Nigeria as well as the creation of TETFund was examined. Also the paper was guided with the use the Management by Objectives theory developed by Drucker in 1954. Emphases were laid on the basic functions of TETFund such as that of project facilitation, funding and staff development. The challenges confronting TETFund and ways of improving TETFund's relevance in Universities in Nigeria were also discussed. It was concluded that if well co-ordinated, TETFund can help to boost the structure of University education in Nigeria. It was therefore recommended that various private organizations should contribute to the empowerment of TETFund and appropriate legislations should be made to assist the agency carry out its activities effectively.
\end{abstract}

KEY WORDS: Management, Staff Training, Tertiary, Education, Funding

\section{INTRODUCTION}

Over the years, the various levels of education in the country have been confronted with various problems which range from financial, human to material resource insufficiencies. It is for this reason that various steps have been taking by the government to restore the dwindling fortune of the nation's educational system. However, most affected among the levels of education within the country is the tertiary level of education especially university education. The university level of education is very strategic in the educational arm of the country since it is the apex among the tertiary education system. As stated by the Federal Government of Nigeria in the National Policy on Education (2004:25), "University education shall make optimum contribution to national development: intensifying and diversifying its programmes for the development of high level manpower within the context of the needs of the nation". The importance of the university system of education cannot therefore be over-estimated. This has resulted in the continuous increase in the number of universities in the country.

As pointed out by Nwafor (1998), the first university established in Nig,eria was the University of Ibadan in 1948. Afterwards, three other universities were established which are University of Nigeria Nsukka, University of Ife now Obafemi Awolowo University lle-lfe, Ahmadu Bello University Zaria by the then regional governments of the Eastern, Western and Northern regions respectively. In addition, University of Lagos now Moshood Abiola University (MAU) was established in 1970 by the Federal Government and University of Benin in 1972 by the Mid-Western regional Government. By 1972, the nation had six Universities in less than twelve years after her independence. However, today, there are 129 universities in the country comprising of 40 Federal, 38 State and 51 Private owned (National Universities

Victoria C. Onyeike, Department of Educational Management, Education, University of Port Harcourt, Rivers State, Nigeria.

Emmanuel O. Eseyin, Department of Educational Management, Education, University of Port Harcourt, Rivers State, Nigeria. 
Commission, 2013).

Although the number of universities in the country is increasing in lips and bounds, surprisingly, none of these institutions have been able to rank among the first 400 in the world (Times Higher Education, 2013). As the giant of Africa, this scenario ought not to be so. It is based on this premise that various commissions and agencies are being set up by government to look deeply into the cause of the academic challenges confronting the university education in Nigeria.

So far, the Ministry of Education and other subsidiaries such as the National Universities Commission (NUC), Tertiary Education Trust Fund (TETFund) have carried out various functions to assist in re-positioning the University system of education to an enviable height. Although a landmark is yet to be made in re-positioning the university system, however, some level of achievements have been made given the impact of the monitoring and coordinating functions of these various bodies such as the TETFund.

\section{STATEMENT OF THE PROBLEM}

The importance of university education in a developing country such as Nigeria cannot be neglected. This is due to the fact that the overall growth and development of the nation is hinged upon the success of the educational sector. The educational sector all over the world plays a key role in providing the needed balance in the form of skilled manpower, inculcation of acceptable societal norm, developing techniques and methodologies that are required for the nation to thrive. However, the basic resources needed to provide quality service delivery in the nation through the educational system are usually in short supply. Therefore, since the overall development of the nation is anchored on the survival of the educational system, all efforts need to be made to ensure that these institutions survive in all of their endeavors. It is based on this premise that various organizations have been set up to see to the overall management, control and monitoring of these institutions. This is to enable them contribute and enhance the economic position of the nation. The Tertiary Education Trust Fund (TETFund) therefore, as one of the intervention agencies of the government has been established with the responsibility of seeing to the survival of the university system. In the face of human, financial and material inadequacies in the nation's tertiary institutions, the standard of teaching, learning, research and community development has continually been threatened. As such, in order to redeem the image or lost glory of these institutions, monitoring agencies are employed to intervene and revamp the tertiary institutions visà-vis position the nation on the path of development via the efficiency and effectiveness of these tertiary institutions.

\section{LITERATURE REVIEW}

\section{The Need for Management by Objectives}

There is need to look at management by objectives (MBOs) and how it can enhance university management. This is because university education in the country was established to contribute to individual and national development in the country.

The theory adopted for the conduct of this study is Management by Objectives (MBO) propounded by Peter F. Drucker (1954). It is one of the prominent theories used in the field of management. This theory is renowned for its ability to guide any organization towards setting and achieving defined goals or objectives.

Management by Objective (MBO) was developed by Peter Drucker and established on the premise that managers should avoid "the activity trap" that is, getting so involved in their day to day activities that they forget to adhere to principles regarding the sustenance of the reason why the organization was established. One of the focal point of Management by Objective was that instead of just a few top-managers taking the center stage on all organizational matters, all managers of sub-units should participate in the strategic planning process. This will help greatly in the implementation of organizational plan. Another idea behind Management by Objective was that managers should implement a range of performance systems which are designed to help the organization to function well. According to Drucker (1954), the principles guiding Management by Objectives are:

$>$ Cascading of organizational goals and objectives

$>$ Specific objectives for each member

$>$ Participative decision making

$>$ Explicit time period

> Performance evaluation and provide feedback

In the face of scarcity of resources in any organization, it is indeed appropriate for organizations to draw out their plans and ensure 
that these scarce resources are specifically targeted towards addressing the planned objectives. As earlier mentioned, resources in an organization could be financial, human or material. These resources are exhaustible and should therefore be used judiciously. However, for utility to be achieved, the objectives of the organization must be clear so that there could be a clear linkage between objectives and resources. Universities education in Nigeria has its role in a sustainable economy. However, the resources to meet this objective are scarce. This is where Management by Objectives becomes important in the achievement of such goals. It is important to state that universities ought to constantly focus on their objectives and ensure that all is done to achieve the needed goals. The university system is usually divided into various sub-units and headed by various heads. Each of these units has specific Faculty or Departmental objective(s) that is being pursued at any point in time. However, effort must be made to ensure that each of the Faculty or Departmental objectives harmonizes for the overall management of the university system. Each Faculty or Department in the University must focus on attaining their goals. For example, the department of sciences may be focused on the training of science oriented students while those in the commercial department will be striving to raise graduates who will manage the commercial sectors of the economy. The research and development unit will focus on carrying out research that will contribute meaningfully to the society. Despite all the various objective(s) pursued by each of these units, they all combine in assisting the university to produce high level manpower for the economy. In this regards, the various departments though in pursuance of their various departmental objectives must similarly bear in mind the need for achieving the big objective which is the University's objective(s). Working with this ideology, the University of Pittsburgh (2012), noted that they usually harmonize Faculty member's career and goal with Departmental and University objectives. In striving for the objective of the institution, effort needs to be made to ensure that the required resources are put in place to ensure the smooth execution of the universities objectives. Each unit therefore has to put their allocated resources into use such that it will not just be used for the sustenance of the unit but must be geared towards the attainment of the university's objectives. The University therefore has to work with clearly defined objectives such that it will be difficult for it to lose focus. In the same vein, all employees either at the administrative, Faculty or Departmental level must constantly move in line with the laid down objective(s). Any deviation from the above may cause the university to begin to major in the minor and minor in the major.

"Management by Objectives is a comprehensive and democratic systemic management style which is work-centered and people-centered" (Liu, 2010:219). The University system is a community comprising of different intellects with diverse ideologies on how to manage the institution. It is therefore appropriate that these various employees are made to harmonize their opinions in such a way that the organizational objective will not be undermined. Superiors and subordinate who have been accorded different level of responsibility and power should be made to work harmoniously for the common good of the institution which is achieving the University's goal. In the same way, educational managers at the Local, State or Federal level also have to collaborate with the internal managers of the University system to ensure the effective management of university system. "Goal is the desired results which one organization will achieve in a certain period of time in the future through efforts" (Liu, 2010:10). The effort of the different managers of the University system whether within or without, must focus on assisting the University to achieve her goals and avoid resource wastage.

\section{The Tertiary Education Trust Fund (TETFund)}

There are various agencies in Nigeria that are responsible for managing the University education system. One of these agencies set up by the government to oversee the monitoring of the university system of education is the Tertiary Education Trust Fund (TETFund). TETFund came into existence in 2011 after it metamorphosed from the Education Trust Fund (ETF) which was established in 1993 (Ogunde, 2011). As an intervention agency, the institution has been responsible for ensuring that the objectives of the public tertiary institutions in the country are met through the provision of necessary resources. Although a new agency; the TETFUNDs presence has been felt in virtually most of the Universities, Polytechnics and Colleges of Education in the country. The focus of this body is to ensure that the tertiary level of education in the country can compete favorably 
with other universities in the continent and around the world.

TETFund has been responsible for the distribution of intervention funds to the various public higher institutions in Nigeria. This includes the Universities, Polytechnics, Colleges of Education and other levels of education. Although the agency also takes responsibility for the funding of other lower levels of education within the country, however, their major task has being in the area of distributing and monitoring fund among tertiary institutions in the country (Ogunde, 2011).

The TETFund is an interventional measure of the Federal Government to tackle inadequate facilities in our tertiary institutions (Nairaland, 2013). This is the major role which the agency has been playing over the years since it came into establishment in 2011. Various government agencies such as the Central Bank of Nigeria (CBN) and the Federal Inland Revenue Services (FIRS) release funds to the TETFUND as a channel for distributing same to the various tertiary institutions within the country. However, funds from the TETFund are usually made available only to public tertiary institutions in Nigeria. In an interview with the former Head of the Civil Service of the Federation, Professor Oladapo Afolabi, by Adeleye (2013), it was noted that the reason for having the TETFUND is actually to assist public tertiary education programme. The TETFund therefore does not put into consideration the management of private tertiary institutions within the country. This on its part has led to much argument for the review of this trend. The mission of the body as spelt out is: To provide focused and transformative intervention in public tertiary institutions in Nigeria through funding and effective project management (SOURCE: TETFund website). TETFund through its activities has also seen to the management of other non-financial needs of the various levels of education in the country. Some of the institutions that have benefited from the TETFUND in one way or the other are: Yaba college of Technology, University of Port Harcourt, Ahmadu Bello University, Zaria, Federal University of Agriculture, Abeokuta, Kano State University among others (SOURCE: TETFund website).

The Tertiary Education Trust Fund (TETFund) has been intervening in the management of universities in Nigeria through a number of activities. Over the years, the
TETFUND has assisted universities in a number of ways which includes:

- Funding

- Staff training and development

- Projects facilitation

\section{Analysis of the Activities of TETFund in Nigeria}

Based on the key responsibilities of the TETFund, there are basically three key areas in which the agency functions. They are:

$>$ Funding

$>$ Staff training and development

$>$ Projects Facilitation

FUNDING: Funds literarily refer to a sum of money set aside for the execution of projects in an organization. The process of making this allocated money available for the facilitation of plans and programmes is referred to as funding. As one of the focus of the TETFund, funds are usually set aside to assist public tertiary institutions to execute most of their programmes whether it is in the short-run or long-run. This is to ensure that the presence of TETFund is felt in almost all the public tertiary institutions in the country. However, a critical analysis of this role of the TETFUND has revealed that most of these institutions are continually in dire need of money to be able to meet up with their plans and programmes. Therefore, since most of these institutions relatively do not feel the impact of these funding roles in their institutions, it is needful that some conditions be considered before this gesture is extended to most of these institutions in the country.

According to Oweh (2013), chief among the constraints bedeviling the educational sector in Nigeria is the issue of poor funding. The TETFund need to note that proper funding is centered on the ability of such funds to meet the needs for which it was planned. The problem of funding education in Nigerian education system has been in existence for a long time. Okojie (2008) in Akpanuko (2012) noted that while the Federal Universities in the country required \#873,312,877,545.45 and State Universities required $\$ 451,601,666,737.59$ in 2004 for three years expenditure, only 196billion was allocated between 2004 and 2006 signifying 14.8\% of the required $\$ 1.3249$ trillion. Such inadequate funding pattern is not ideal for the nation's universities which are the apex learning institution in the country. This is because; such funding will not be able to cater for projected expenditure and in 
some cases may eventually not be accounted for. Usually, partially funded projects always become fresh projects in most cases and should therefore be seen as an avenue for waste. This is similar to the case of the Niger Delta East-West road which has gulped billions of dollars for more than a decade and still remains an uncompleted project. This is also the case of most universities in the country which continues to have uncompleted projects as a result of inadequate funding.

Therefore, TETFund should learn to handle one project at a time and fund such a project to a logical conclusion. For example, rather than execute a $\$ 5$ million project with \#2million and prolong completion of such projects due to the absence of the 3 million balance, it will be ideal to fund lesser projects that will touch the lives of the members of the beneficiary institutions rather than have gigantic projects which will remain uncompleted for a long time.

Funding should be fully executed and funding programmes that are less cumbersome should be considered so as to avoid partial funding which in the long run will lead to embezzlement, unaccountability and waste.

PROJECT FACILITATION: Aside the funding of Universities, TETFund also assist in the facilitation of projects. Project facilitation just like the funding function of the TETFund should be carried out with a zero exclusion ratio. That is, in monitoring and ensuring project execution, the TETFund should endeavor to monitor projects to the extent that such projects can make effective contribution to the administration of the university system where such projects are situated. Based on agreed criteria, the TETFund should ensure that the ratio of projects to teachers and/or students should be reasonable enough for efficient and effective teaching, learning, research and community development. Due to the importance of facilities in the administration of tertiary education in the country, the quantity and quality of projects should be such that can contribute to the management of the education system. Students and teachers should be able to feel the impact of facilities made available in the benefiting institutions. It should not be mere lips service that facilities have been provided, but rather, the agency should ensure that such facilities are qualitative enough. The TETFund should be involved in assisting institutions facilitate projects that will be of benefit. This role can be carried out by collaborating with the
National Universities Commission (NUC). This is to ensure that available facilities are able to cater for the programmes being run in these universities. Clear reports from our universities reveal beyond reasonable doubt that available facilities such as Classrooms, Laboratories, Workshops, Libraries, Office Spaces, Canteens and Common Rooms etc are grossly inadequate for both teachers and students. As such, when the word 'project facilitation' comes to the fore, any one project that the TETFund intends to execute should be such that its impact will be felt the university community. The essence of any project in the university environment is only achieved when it is able to add value to teaching, learning, research and community development and this should be the watch-word for the agency.

STAFF TRAINING AND DEVELOPMENT: The importance of staff training and development in any organized institution cannot be ignored most especially in the university system. According to Ebong and Ezekiel-Hart (2006:168) "training is crucial as one of the staff development procedure. An employee may have the qualification needed for a job, but may not have the necessary experience and skills to perform the task required effectively". Based on this premise, one can identify that the productivity of an employee in any organization especially in the educational sector is majorly dependent on the level of training acquired on the job. Therefore, in order for the staff of the university to function effectively, they need to be trained continuously. In fact all staffs of the university system whether academic or no-academic should be exposed on the best practices of their responsibilities at work. Most of academicians have also requested that the activities of the TETFund in terms of human capital should be extended to the non-academic staff just like their academic counterpart (Ogar, 2012). This is a necessity because this staffs jointly work for the advancement of the university and the quality of their input at work is of utmost importance in enhancing the image of the university. Therefore, since all staff of the University plays one major role or the other in ensuring the effective administration of the institution, they should all be exposed to quality training and development in order to improve on their capacity building. For example, while the bursar is trained on ways to generate and manage university funds, the Librarian should be trained on how to develop the knowledge 
capacity of the university, lecturers should be trained on new methods and techniques and nonacademic staffs should be enlightened on best practices. All of these will go a long way in enhancing the quality of the University system.

\section{The TETFund and Private Institutions in Nigeria \\ Emphasis has usually been laid on the} role of the TETFUND as a public tertiary institutions intervention agency. The agency has continually intervened in the monitoring of public Universities, Polytechnics and Colleges of Education among others. However, most of the private institutions in the country have continued to bear their mind on the injustice embedded in this kind of policy. According to Ajayi and Ekundayo (2008) tertiary institutions in the country either public or private are jointly responsible for the overall development and transformations of the country. Teaching, research, community development and other functions performed by these institutions are geared towards the overall advancement of the national economy. Proponents have indicated that products of these private institutions have become productive employees in the various sectors of the country. Therefore, the need for private tertiary institutions in the country to be properly involved in the activities of TETFund in the country cannot be ignored.

One of the reasons why the TETFund cannot ignore the need to intervene in the activities of private tertiary institutions in the country is that it was revealed that out of the 1.7million students that sat for the 2012/2013 Unified Tertiary Matriculation Examination (UTME), the nations Universities, Polytechnics and Colleges of Education only 500,000 students can be accommodated (Scan News, 2013). The capacity to absorb this figure includes both public and private tertiary institutions in the country. Since these private universities help to balance the quantity and quality of tertiary education available in the country, they need to be integrated in government's intervention programmes for better service delivery. Also, the Vice Chancellor of Bowen University, Olagbemiro in Adesulu (2012) stated that what private universities need is encouragement and financial assistance to better their lot and add substantial value to the lives of Nigeria's teeming youth. As such, the private institutions need to be provided with the financial and material wherewithal with which they can improve on the absorption capacity of the nations tertiary institutions. In the same vein, the sources of funding accruing to the TETFund includes taxes raised from the private sector which includes the private institutions, and as such they should not be neglected in benefiting from the revenue which is generated from the private sector.

Furthermore, it is hoped that when these private institutions are provided with the needed resources; human, financial and material, they would be able to expand their capacity to accommodate prospective tertiary education seekers in the country. In fact, administrators of these private institutions have observed that with assistance, they can be able to provide quality education for the less privileged in the country. The expansion of private University education in the country will provide opportunity for most youths in the country to acquire tertiary education.

Therefore, neglecting the private universities of our tertiary education system despite their enormous contribution towards manpower development and nation building will not go down well with justice. This is because, graduates of private tertiary institutions in the country are products which will be deployed to revamp and contribute meaningfully to the success of most sectors of the economy not minding which type of institution that they actually graduated from.

It is important to point out the fact that in cases of joint development in the country, either in the area of technology, agriculture or political development through public-private synergy, most private institutions in the country will lack the willingness due to shortage of resources to partner with colleagues from the public institutions. The interest of the private institutions will be minimal considering the fact that they would have little or no encouragement to contribute immensely towards national development. This is the case when intervention agencies such as TETFund do not put them into consideration in their activities.

Advisedly therefore, a step in the right direction will actually make a significant difference. As such, either in the area of funding, infrastructural development or manpower training and development, the presence of the TETFund should be made noticeable in the nation's private tertiary institutions just like that of the public tertiary institutions. This will go a long way in improving the quantity and quality of tertiary education in the country. Output from tertiary 
education can therefore be improved through governments intervention in private tertiary institutions within the country.

\section{Challenges Confronting the TETFund in Nigeria}

The TETFund just like most other organizations is confronted with some level of challenges. It is by overcoming some if not all of these challenges that the agency can be guaranteed of success in her overall activities. Some of the challenges confronting TETFUND in the execution of its functions include but not limited to the following:

1. Government Policy: one of the policies of the government which can be said to have curtailed the scope of operation of the agency is in the area of limiting their role to that of intervening in only the nation's public tertiary institutions and not the private. Government directives in some cases have the capacity to expand or minimize the function of various agencies in the country. The case is not different for the TETFund. Funds generated by the agency are subject to some prescribed governmental policies. As such, the agency lacks the freedom to express their will on how their activities should be coordinated. This has in some way being a hindrance to the function of the agency.

2. Funding: Funding has remained a major challenge to almost all the sectors of the Nigerian economy. This is because funding is a very vital resource in the course of executing a strategic function like that which is executed by the TETFund. The activities of TETFund in Nigeria is highly capital intensive. The agency needs money in order to keep up with the financial, human and material needs of all the tertiary institutions in the country. The projected expenditure of the agency is usually higher than generated income. The agency therefore becomes incapacitated to execute effectively the sole responsibility which it is expected to carry out. Suffice it to say that the absence of adequate funds will either slow or totally ground the ability of the TETFUND to carry out the most important plans laid down ahead of it.

3. Level of Cooperation between TETFUND and Benefiting Institutions: one of the areas in which the agency has been restricted in executing her responsibility is in the area of smooth cooperation between the agency and most of the benefiting institutions within the country. While some institutions assume that the agency usually adopts bias criteria in funding tertiary institutions in the country. Other institutions inflate facts and figures in order to acquire an undue advantage from the agency. This has made the working relationship between the TETFund and these institutions to be distorted. Therefore, the agency has more analysis to do in order to ensure that it is not blind folded in the conduct of her responsibilities.

4. Overloading of Responsibilities: The TETFund over time has been experiencing challenges in the area of clear definition of responsibilities. Although the TETFund has been linked to be an intervention agency in the monitoring of the affairs of tertiary institutions. However, there are cases where the TETFund has been involved in the funding of lower levels of education such as the primary and secondary levels. Therefore in the midst of the inadequacy of resources available to the agency, the agency remains yet overcrowded with the responsibility of attending to the various other levels of education in the country. As such, the agency needs to constantly strategize on how to manage available resources with demand from the various levels of education in the country. This has been a serious challenge for the agency over time.

Other challenges identified by TETFund in the conduct of her functions are:

- Neglect of institutions by their proprietors

- Boosting the confidence of stakeholders

- Effective financial and project monitoring

- Unnecessary political interference

- Inexperienced desk officers

- Lack of capacity to utilize funds

- Ability to enhance and boost teachers morale

- Increase in revenue generation

\section{Ways of Improving the TETFund's Activities} in Nigeria

In order to guarantee the effective functioning of the TETFUND, it is necessary that the activities of the agency be reviewed and possible ways be fashioned out in order to ensure the proper functioning of the agency. Some of the ways through which the TETFUND can be re-positioned for better service delivery in the nation's tertiary institutions will include the following:

1. Review of the current $2 \%$ company tax: the major source of funding available to the TETFund remains the $2 \%$ company tax collected from companies that have employees of over 100 employees (TETFund website). Surprisingly, the 
physically and mentally skilled labour turned out of these tertiary institutions end up becoming perspective employees in the various organizations in the country. Therefore, as a way of assisting the agency, the $2 \%$ company tax need to be reviewed to a range between $3 \%$ to $5 \%$ so as to provide enough fund for the agency to execute her major objectives. In a related manner, the companies remitting their returns to the agency through the Federal Inland Revenue Service (FIRS) should be made to include companies with employees below 100 persons. This could be considered at a tax rate of between $0.5 \%$ to $2 \%$ for companies with 100 employees and below. This is one of the avenues through which more funds can be made available to the agency in order to assist the nation's tertiary institutions. The increase in funds will have its multiplier effect in the area of increase in the quality and quantity of graduates that will empower the various sectors of the different units of major organizations within the country and also various sectors of the economy.

\section{Establishing TETFUND Units in} Universities: another way of re-positioning the role of the TETFund is establishing the TETFund units in the various tertiary institutions in the country. This unit can also be established as a sub-unit of any other monitoring agency in the benefiting institution. Such units should be properly empowered to carry out this function. The essence of establishing this unit closer to the benefiting institution is to ensure close monitoring of funds and programmes in these institutions of learning. A representative of the TETFund in these institutions will help to ensure that funds are used for their intended purpose and that projects are facilitated to conclusion. In the same way that we have internal control units of various organizations in the country, the TTETFund units will help to ensure that beneficiary institutions carry out projects accurately and at the right time. Supervision of projects can be closely done and the risk and cost of travelling by the national members of the agency will be reduced. Similarly, these TETFUND subunits will also advice the agency in areas where they think the benefiting institutions is in dire need of the agency's intervention.

3. Publishing TETFund's Activities: in order to guarantee accountability and transparency, the activities of the TETFund in collaboration with the tertiary institutions that are being assisted should be made public in the form of monthly, quarterly, bi-annual or annual report to the general public. This will assist in ensuring transparency in the rapport between the TETFund and the beneficiary institutions. This is related to the suggestion of Yusuf (2010) who opined that a public accountability strategy should be adopted by learning institutions such that they will present their score card to the public in the form of annual report presented by profit making organizations. This will assist members of such learning institutions, the public and government become aware of the activities transpiring between the agency and the institutions. Based on this, the general public can make input on how they feel this collaboration can be better enhanced.

4. Private Sector Participation: the role of the private sector in enhancing the activities of the TETFund in our university system cannot be over-emphasized. The TETFFund will benefit from private sector participation in one or more of the following ways:

1. The agency can secure loan from private organizations to meet up with emergencies in our learning institutions which they can reimburse later in the future. Such loans can be from banks, mortgage firms and other financial institutions.

2. The services of national and international staff training organizations can be employed to assist in the training of personnel in our institutions both within and outside the country. This can be done on regular basis as the need arises.

3. The private sector can also assist in the area of projects development in these institutions which will meet with international standard and enhance learning.

The private sector can also render philanthropic services either in cash or in kind to the agency to facilitate the activities of the agency in their host institutions of learning in order to ensure proper coordination.

5. Freedom of Operation: As a government intervention agency in the nation's tertiary institutions, the TETFund is susceptible to politicking. This is because so many interest and interest groups are usually considered before enforcing any programme organized by the agency. Therefore, another way of ensuring the efficiency and effectiveness of the agency is to give it a free hand to coordinate its own activities. There should be little or no governmental influence in ordering the programmes of the 
agency. The agency has facts and figures about the needs of these institutions and should therefore be given a free will to operate so as to enable it achieve laudable achievements in our tertiary institutions.

\section{CONCLUSION}

The role of University education in the growth and development in Nigeria cannot be over-emphasized. The extent to which national objectives are achieved in the country is subject to how well the university system is attended to. Similarly, for the university system to perform well, the effort of all educational stakeholders and agencies must be on deck. It is on this note that the activities of TETFund become necessary.

\section{RECOMMENDATIONS}

Given the present scenario in which Nigerian Universities operate, the following recommendations are made:

1. Private Universities should be involved in the activities of TETFund as they also contribute to the advancement of the various sectors of the national economy.

2. The various firms and industries that operate in Nigeria should contribute financially to the activities of TETFund as part of their social corporate responsibility for the advancement of university education in Nigeria.

3. TETFund should also be provided with appropriate legislations that will make it easier for them to carry out their various activities within the country.

\section{REFERENCE}

Adeleye, S., April 17, 2013. Government Should Not Politicize Education. Retrieved from http://dailyindependentnig.com/2013/04/g overnment-should-not-politiciseeducation-afolabi/

Adesulu D., 2012. Why Private Universities should be part of TETFund. Retrieved from http://www.vanguardngr.com/2012/ 11/why-private-varsities-should-bepart-of-tetfund/

Ajayi, I. A and Ekundayo, H. T., 2008. The Deregulation of University Education in Nigeria: Implications for Quality
Assurance.

Retrieved

from www.nobleworld.biz/images/Ajayi $\mathrm{E}$ kundayo.pdf

Akpanuko, E. E., 2012. Tertiary Education Development and Sustainability in Nigeria: Beyond Financial Accountability: Journal of Economics and Sustainable Development, 3, (8):

Drucker, P. F., 1954. The Practice of Management. United Kingdom: Heron Books

Ebong, J. M and Ezekiel-Hart, J., 2006. Contemporary Issues in Education. Port Harcourt: Eagle Lithograph Press

Federal Republic of Nigeria., 2004. National Policy on Education. Lagos: NERDC

Liu, X., May, 2010. On Application of MBO in College Management: International Education Studies. 3(2); 219-223 Retrieved from http://www.ccsenet.org/journal/index.php/ ies/article/download/5892/4665

Nigerian Universities Commission, (NUC)., 2013. www.nuc.edu.ng/pages/universities.asp? ty=2\&order=inst.name

Nwafor, S. O., 1998. Higher Education Administration: Issues and Prospects. Port Harcourt: Etibeng Communications

Ogar, M., 2012. Registrars Implore TETFUND to Sponsor Non-Academic Staff for Trainings. Retrieved fromhttp://www.guar diannewsngr.com/index.php?option=com content\&id=90594\%3Aregistrarsimplore-TETFUND-to-sponsor-nonacademic-staff-for-trainings $\&$ Itemid $=610$

Ogunde, A., 2011. Nigerians Spend Over \$2 Billion Annually On Foreign Degrees. Retrieved from http://businessnews.com. ng/2011/12/22/nigerians-spend-over-2billion-annually-on-foreign-degrees/

Oweh, I., 2013. A Case for Better Educational Funding in Nigeria. Retrieve from http://dailyindepende ntnig.com/2013/01/a-case-for- 
better-educational-funding-innigeria/

Scan News., April 28, 2013. UTME: Only 500,000 Prospective Students to Gain Admission to Nigerian Universities. Retrieved from http://scannewsnigeria.com/featuredpost/utme-only-500000-prospectivestudents-to-gain-admission-to-nigerianuniversities/

TETFUND., 2013.http://www.TETFUND.gov.ng/in dex.html Times Higher Education., 2013. World University Ranking 2013-2014. Retrieved from http://www.timeshighereducation.co.uk/w orld-university-rankings/2013-14/worldranking

Yusuf, L. A., 2010. Resourceful Financial Management as Panacea for University Sustainability in a Depressed Economy: Pakistan Journal of Social Sciences. $7,(5): 347-350$ 